\title{
ANALISA TERBENTUKNYA OPINI PUBLIK NEGATIF UNDANG-UNDANG CIPTA KERJA DI KALIMANTAN SELATAN
}

\section{ANALYSIS OF THE NEGATIF PUBLIC OPINION ON THE JOB CREATION ACT IN SOUTH KALIMANTAN}

\author{
Irwansyah $^{1}$, Ahmad Alfin Ferdian², Enni Rizqa Zulfiana ${ }^{3}$, dan Muzahid Akbar Hayat ${ }^{4}$ \\ 1,2,3,4 Universitas Islam Kalimantan Syekh Muhammad Arsyad Al Banjari Banjarmasin \\ Jl. Adhiyaksa No. 2 Kayu Tangi Banjarmasin, Kalimantan Selatan, Indonesia \\ e-mail: marley.kalpost@gmail.com
}

Diserahkan: 19/12/2020; Diperbaiki: 16/05/2021; Disetujui: 23/05/2021

DOI: $10.47441 /$ jkp.v16i1.142

\begin{abstract}
Abstrak
Undang-Undang Cipta Kerja (UU Ciptaker) yang telah disahkan pada tanggal 5 Oktober 2020 mengalami gejolak penolakan berupa unjuk rasa hampir di seluruh wilayah Indonesia. Unjuk rasa penolakan tersebut sebagai bentuk negatif dari opini publik yang secara bersamaan mengalami ketidakpastian akibat pandemi Covid-19. Banyak terdapat kesalahpahaman dalam penafsiran undang-undang tersebut, salah satunya adalah bahwa undang-undang tersebut dianggap sangat merugikan buruh dan masyarakat. Penelitian ini bertujuan untuk mengidentifikasi penyebab terjadinya opini publik negatif terhadap UU Ciptaker, apa saja bentuk sosialiasi yang dilakukan oleh pemerintah terhadap regulasi tersebut, dan bagaimana masyarakat di Kalimantan Selatan mendapatkan sumber informasi terhadap adanya undang-undang tersebut. Penelitian ini menggunakan pendekatan kualitatif. Data diambil melalui kuesioner yang disebarkan kepada 22 responden yang dipilih secara acak dari demonstran UU Ciptaker yang terjadi pada bulan November 2020 di depan Gedung DPRD Provinsi Kalimantan Selatan. Hasil penelitian menunjukkan opini negatif responden terhadap UU Ciptaker disebabkan oleh kurangnya pengetahuan mengenai isi UU tersebut dan minimnya sosialisasi pemerintah kepada masyarakat. Strategi yang dapat dilakukan oleh pemerintah untuk menciptakan opini publik positif adalah melibatkan kelompok masyarakat, mahasiswa, publik figur, tokoh agama, tokoh masyarakat, dan influencer sebagai komunikan atau penyampai pesan dalam sosialiasi UU Ciptaker.
\end{abstract}

Kata Kunci : Cipta Kerja, Opini Publik, Media, Komunikasi Politik

\section{Abstract}

The Job Creation Act which was ratified on 5 October 2020 was met with agitation of rejection in the form of demonstrations in almost all parts of Indonesia. There are many misunderstandings in the interpretation of this law, one of which is the assumption that the law will harm workers and society. This study aims to identify the causes of negative public opinion on the Job Creation Act, what forms of socialization are carried out by the government, and how the public gets information about the law. This research uses a qualitative approach. The data was taken through a questionnaire distributed to 22 respondents who were randomly selected from the demonstrators of the Job Creation Act that took place in November 2020 in front of the DPRD Building of South Kalimantan Province. The results showed that respondent's negative opinion on the Job Creation Act was caused by a lack of knowledge about the contents of the law and the lack of government socialization to the public. The strategy that can be taken by the government to create positive public opinion is to involve community groups, students, public figures, religious leaders, community leaders, and influencer as communicants or messengers in the socialization of the Job Creation Act.

Keyword : Job Creation, Public Opinion, Media, Political Communication 


\section{PENDAHULUAN}

Masyarakat mempunyai pandangan atau pendapat (opini) sendiri dari sebuah keputusan politik yang diambil pemerintah. Jika digabungkan pendapat beberapa masyarakat atas keputusan politik disebut opini publik. Sebagaimana disampaikan Rush dan Alfhoff, transmisi informasi dari satu sistem politik dengan sistem politik lainnya merupakan komunikasi politik. Sistem politik dan sistem sosial termasuk unsur dinamis dari suatu sistem politik (Susanto, 2017). Pandangan dan respon dari sebuah keputusan politik tersebut mendorong komunitas masyarakat dan mahasiswa di Kalimantan Selatan (Kalsel) turun ke jalan selama beberapa hari. Aksi demonstrasi terjadi di depan kantor DPRD Kalsel di Jalan Lambung Mangkurat Banjarmasin setelah pengesahan Undangundang Cipta Kerja (UU Ciptaker) pada Oktober 2020 lalu. Aksi demonstrasi terjadi lebih dari 1 hari dan diikuti ratusan orang, meski di tengah pandemi Covid-19 yang belum terkendali. Aksi saling dorong antara demonstran dengan aparat keamanan tidak dapat dihindarkan. Bahkan, karena demonstran memaksa bertahan di lokasi demo, maka aparat keamanan membubarkan secara paksa. Tuntutan para demonstran adalah agar DPRD Provinsi Kalimantan Selatan menyampaikan kepada Pemerintah Pusat untuk membatalkan pemberlakuan UU Ciptaker. Aksi yang melatarbelakangi demonstrasi yaitu adanya opini masyarakat bahwa UU Ciptaker lebih berpihak pada pengusaha dan cenderung merugikan rakyat atau buruh. Salah satu isi pasal yang mereka anggap merugikan tersebut adalah dihilangkannya pesangon bagi pekerja yang diberhentikan.

Aksi para demonstran ini bukan lagi soal sikap terhadap regulasi yang dikeluarkan, namun sudah mencakup opini. Bentuk opini publik yang disampaikan melalui unjuk rasa tersebut merupakan bagian dari komunikasi politik. Efek dari suatu proses komunikasi politik salah satunya adalah opini publik. Saluran media massa salah satu wahana untuk membentuk opini publik. Media massa sering menjadi sumber informasi dan sebagai saluran komunikasi bagi politis. Peranan opini publik dan media sangat penting dalam proses kebijakan. Liputan terus menerus oleh media mempengaruhi perilaku publik (Rianto, 2010). Disebutkan Sirait dan Cindoswari dalam penelitiannya, pemberitaan yang disampaikan dapat berupa audio, visual, audio visual yang di dalamnya terapat simbol yang dimuat pada media elektronik atau media cetak. Apa yang disampaikan media acapkali memunculkan pendapat atau disebut opini publik (Sirait dan Cindoswari 2018).

Lebih jauh menurut Heryanto, konsep dan keberadaan ruang publik (public sphere) tidak dapat dipisahkan dengan komunikasi politik. Jawaban atas kondisi yang terjadi di ruang publik yang hadir dan terbentuk adalah sebuah proses dari komunikasi politik. Dalam waktu singkat dan cepat, ruang publik dibanjiri dan sesak dengan pesan-pesan politik yang menggiring serta membentuk opini publik (Heryanto, 2020). Hal ini diperkuat pernyataan Tabroni, bahwa opini dan sikap memiliki pengertian yang berbeda. Walaupun, pada kedua istilah itu terdapat suatu interaksi yang berkesinambungan. Sikap ada dalam diri seseorang, sedangkan opini (pernyataan atau ekspresi) keluar dari diri seseorang. Dengan demikian, terdapat suatu kerjasama yang berkesinambungan antara opini dan sikap, atau sebaliknya di dalam diri manusia dalam menghadapi suatu masalah atau situasi tertentu (Tabroni, 2012). Terdapat beberapa faktor penting dalam proses pembentukan opini, antara lain latar belakang, sejarah, faktor biologis, faktor sosial, dan faktor psikologis (Cangara, 2011).

Opini negatif terhadap UU Ciptaker disebabkan oleh faktor latar belakang yang disebabkan kurangnya sosialisasi dan komunikasi yang dijalin pemerintah dengan publik. Sumber informasi masyarakat Kalimantan Selatan tentang UU Ciptaker kebanyakan berasal dari media massa. Pada posisi ini media massa berperan besar membentuk opini publik. Berdasarkan penelitian terdahulu, media massa memiliki pengaruh yang sangat besar dalam membangun masyarakat multikultur karena fungsinya yang sangat potensial untuk mengangkat opini publik sekaligus sebagai wadah berdialog antar lapisan masyarakat. Apalagi terkait pada isu keragaman budaya seperti dalam kehidupan masyarakat di Indonesia yang mulkulturalisme (Trijanto, 2015). Media massa juga menjadi 
pilihan dalam penyampaian pesan politik. Berdasarkan penelitian terdahulu, media massa menjadi faktor dalam berbagai kepentingan politik, karena media dapat membentuk atau menyampaikan opini masyarakat, entah itu benar atau hanya berupa manipulatif dan propaganda, asalkan tujuan dari politiknya dapat tercapai di kemudian hari (Tijayanto, 2015). Opini publik juga sering dikatakan sebagai kekuatan politik dan menjadi dasar negara demokrasi (Tabroni, 2012). Opini publik adalah salah satu bentuk efek dan pesan politik dalam proses komunikasi yang bersumber dari politisi, misalnya akan menjelma menjadi pesan politik dari publik kepada politikus melalui media massa. Dengan demikian, politik yang pada awalnya berperan sebagai sumber pesan politik akan berubah menjadi penerima pesan atau informasi, dan publik akan berubah menjadi sumber pesan atau informasi tentang opini publik yang tercipta. Komunikasi yang bersifat timbal balik dan dua arah ini diperankan oleh media massa sebagai alat penyalur (Tabroni 2012).

Berdasarkan penelitian terdahulu, menyebutkan media harus dipandang sebagai pelaku penting dalam politik. Tanpa media, komunikasi politik tidak mungkin berjalan dua arah antara komunikator politik dengan masyarakat, maupun sebaliknya (Indrawan, 2017). Masih berdasarkan penelitian terdahulu, media massa seperti koran, televisi, majalah, dan radio paling banyak dan paling murah untuk menyampaikan pesan kepada masyarakat (Melissa, 2013). Pengaruh penting dalam pembentukan sebuah opini publik lainnya yaitu adanya peran komunikan. Peran seorang komunikan juga sangat menentukan untuk membentuk suatu opini. Komunikan bisa tokoh politik, tokoh masyarakat, tokoh agama, maupun influencer. Hasil penelitian terdahulu menyebutkan para ulama menentukan strategi komunikasi politik untuk membentuk opini terutama bagi warga Nahdliyin Pancor yang belum memiliki dukungan pada pesta demokrasi (Sofyan, Laksono, dan Chabibi, 2019). Menciptakan suatu opini melalui media massa merupakan pilihan bijak yang dapat diambil oleh seorang komunikator politik.

Masyarakat saat ini cukup peduli terhadap segala bentuk pemberitaan. Dulu hanya orang terpelajar serta orang kaya yang memerlukan berita, namun saat ini hampir semua lapisan masyarakat ingin mengetahui berita terkini. Selain itu, media massa juga bisa berperan sebagai pembentuk opini melalui pemberitaan yang disajikan. Hal itu pernah terjadi sebagaimana dalam penelitian yang dilakukan oleh Wanody (2018), yaitu gagasan dan perilaku umat Islam berpengaruh pada opini publik yang mencerminkan umat Islam sebagai aktor kekerasan, kebencian, miskin, dan tertinggal. Berdasarkan paparan di atas, melalui penelitian ini penulis ingin mengungkap penyebab tercipta opini publik negatif tentang UU Ciptaker. Fakta kedua yang ingin diketahui bagaimana sosialisasi yang dilakukan pemerintah terkait regulasi baru tersebut. Terakhir, juga ingin diketahui dari mana masyarakat Kalimantan Selatan mengetahui undang-undang tersebut.

\section{METODE PENELITIAN}

Desain penelitian ini bersifat kualitatif dengan metode deskriptif. Penelitian dilakukan di Kota Banjarmasin pada bulan November 2020, saat terjadi unjuk rasa UU Ciptaker di depan Kantor DPRD Provinsi Kalimantan Selatan. Populasi penelitian adalah 200 demonstran yang terdiri dari unsur komunitas masyarakat dan mahasiswa, sedangkan responden diambil sebanyak 22 orang yang dipilih secara acak pada titik-titik kumpulan demonstran yang berbeda dengan metode purposive random sampling. 22 orang responden ini diasumsikan telah dapat mewakili populasi. Pengumpulan data dilaksanakan melalui observasi dan wawancara dengan responden. Analisis data dilakukan dengan membandingkan hasil wawancara dengan isi naskah UU Ciptaker, dan disajikan secara deskriptif. 


\section{HASIL DAN PEMBAHASAN}

Undang-undang No. 11 Tahun 2020 tentang Cipta Kerja atau disingkat UU Ciptaker, juga dikenal dengan sebutan Omnibus Law, disahkan oleh DPR RI pada tanggal 5 Oktober 2020 dan diundangkan pada 2 November 2020. Regulasi yang berisikan ratusan pasal ini disahkan pada saat masyarakat sedang mengalami ketidakpastian akibat pandemi Covid19 yang mewabah sejak awal tahun silam. Jauh sebelum DPR RI mengesahkan undangundang ini, sebagian masyarakat sudah menyuarakan penolakan karena menganggap masalah pandemi lebih mendesak daripada regulasi tersebut. Ketika undang-undang ditetapkan, penolakan dari masyarakat semakin kuat dan semakin besar. Terjadi demonstrasi menolak undang-undang tersebut, bahkan masyarakat yang dianggap sebagai penggerak demonstrasi diproses secara hukum. Aksi penolakan melalui unjuk rasa di depan umum tersebut sudah termasuk kategori opini publik. Sebagaimana dikatakan ahli komunikasi, sikap memiliki pengertian yang berbeda dengan opini. Meskipun tak bisa dipungkiri pada kedua istilah tersebut terdapat suatu interaksi yang berkesinambungan. Opini (pernyataan atau ekspresi) keluar dari diri seseorang, sementara sikap berada di dalam diri seseorang. Dengan demikian terdapat suatu kerja sama yang berkesinambungan antara opini dan sikap, atau sebaliknya di dalam diri manusia dalam menghadapi suatu masalah atau situasi tertentu.

Unjuk rasa penolakan UU Ciptaker yang terjadi di Kalimantan Selatan ini termasuk dalam kategori opini publik. Media massa sering menjadi sumber informasi dan sebagai saluran komunikasi bagi politisi. Media juga berperan dalam menyampaikan pemberitaanpemberitaan politik. Meski media sosial lebih mudah diakses, namun urusan komunikasi politik masyarakat lebih dominan bergantung pada media massa. Dari total responden terdapat 59 persen di antaranya menjawab mengetahui UU Ciptaker dari media massa, sedangkan selebihnya dari media sosial. Sebagaimana teori, komunikasi politik hadir membentuk sekaligus jawaban atas kondisi yang terjadi pada ruang publik. Dalam waktu singkat dan cepat ruang publik dibanjiri dan sesak dengan pesan politik yang menggiring serta menciptakan opini publik. Hal ini sejalan dengan yang terjadi baik sebelum maupun sesudah pengesahan UU Ciptaker di mana ruang publik terbentuk opini.

Publik membuat kesimpulan yang mana sebagian menolak dan melancarkan aksi unjuk rasa adalah sebuah respon dari proses komunikasi politik. Berdasarkan data peneltian, terbentuknya opini publik negatif dilatarbelakangi oleh kurangnya informasi dan pengetahuan terhadap subtansi isi undang-undang tersebut. Sangat jarang masyarakat mau mempelajari lebih jauh apa saja kelebihan dan keuntungan dengan diberlakukannya undang-undang tersebut. Kurangnya informasi dan pengetahuan tersebut dapat diketahui dari hasil wawancara. Hanya $22 \%$ responden yang mengetahui atau mempelajari substansi UU Ciptaker. Dari sini dapat dikatakan opini terbentuk karena kekurangan informasi atas substansi undang-undang. Ketika ditanya mengapa tidak mempelajari substansi undangundang jawaban responden beragam. Ada yang mengatakan masih bingung, ada yang menjawab mempelajari sedikit hanya mengetahui dari ahli dan membaca pesan pada sosial media, bahkan ada yang memberikan jawaban tidak merasa perlu mempelajari.

Selain memang isinya yang begitu banyak sehingga sulit dipelajari, responden juga merasa kesulitan menemukan draf final undang-undang tersebut. Sebagian responden lagi merasa kebingungan untuk mempelajarinya. Gambaran tersebut sesuai dengan kutipan wawancara berikut, "[....]menurut saya walaupun tidak dipelajari dengan baik mengenai UU Ciptakerja sudah terlihat buruk dengan adanya RUU yang terburu-buru dan ditutuptutupi saat pengesahan. Menurut saya hal demikian menunjukkan ketidakbenaran, karena Omnibus Law dibuat untuk kepentingan rakyat, kenapa kesannya malah tertutup untuk rakyat dan drama-drama yang terjadi sudah cukup membuktikan bahwa ada unsur kepentingan dari RUU Omnibus Law yang dibuat secepat kilat"'.

Sebagian responden menilai UU Ciptakerja lebih banyak hal yang merugikan daripada hal yang menguntungkan. Pendapat tersebut dapat diketahui ketika responden 
diminta penilaian tentang undang-undang tersebut. Sebagian menjawab membuat kegaduhan, sebagian lagi menjawab tidak meningkatkan perekonomian, ada juga yang menjawab memanjakan pengusaha, serta terdapat juga jawaban beberapa poin di UU Ciptaker merugikan masyarakat. Beberapa responden memberikan jawaban yang beragam dan langsung menilai negatif kinerja pemerintah. Berikut diantaranya kutipan wawancara, yaitu "Penilaian saya pemerintah sangat terburu-buru karena sudah tau akan didemo kenapa malah disahkan. Padahal pemerintah tegas mengurus virus corona, tetapi malah bikin orang kumpul-kumpul seperti demo. Ada apa dengan DPR dan pemerintah?". Responden lainnya menambahkan, yaitu "Saya tidak berani menilai karena tidak mengetahui isinya secara pasti. Yang saya tangkap dari isu yang beredar pada media sosial, banyak celah bagi pengusaha untuk memanfaatkan agar merusak lingkungan tanpa harus bertanggung jawab".

Opini publik negatif atas undang-undang tersebut memang sudah tercipta, berdasarkan jawaban responden. Meski memiliki jawaban yang beragam, akan tetapi semua responden sepakat bahwa UU Ciptaker lebih banyak memiliki dampak buruk atau hal-hal negatif dari pada positif. Hal-hal negatif yang dimaksud responden diantaranya menekan para pekerja, sangat merugikan rakyat kecil, merugikan buruh, dan terutama merugikan terkait permasalahan lingkungan. Sebagian lagi menilai hal negatif terkait masa cuti dan pesangon yang dihilangkan, serta sistem penggajian pekerja berdasarkan jam kerja. Opini publik tersebut terjadi dikarenakan ketidaktahuan masyarakat atau informasi dan pengetahuan yang kurang terhadap substansi UU Ciptaker. Sebagian dari responden menilai hak-hak cuti karyawan berkurang bahkan dihilangkan melalui UU Ciptaker. Jika dipahami dan dipelajari dengan baik, pada UU Ciptaker telah mengakomodir hal-hal yang menjadi penilaian negatif dari publik tersebut. Adapun pasal-pasal yang dianggap merugikan tersebut yaitu pasal 79, pasal 156, dan pasal 157.

Pasal 79 terkait pemberian waktu istirahat dan cuti bagi pekerja/buruh. Adapun isi dari pasal tersebut yakni pengusaha wajib memberi waktu istirahat cuti: (a) istirahat antara jam kerja, paling sedikit setengah jam setelah bekerja selama 4 jam terus menerus dan waktu istirahat tersebut tidak termasuk jam kerja; dan (b) istirahat mingguan 1 hari untuk 6 hari kerja dalam 1 minggu. Istirahat mingguan wajib diberikan kepada pekerja/buruh yang cuti tahunan, paling sedikit 12 hari kerja setelah pekerja/buruh yang bersangkutan bekerja selama 12 bulan secara terus menerus. Pelaksanaan cuti tahunan ini harus diatur dalam perjanjian kerja, peraturan perusahaan, atau perjanjian kerja bersama. Selain waktu istirahat dan cuti, perusahaan tertentu dapat memberikan istrahat panjang yang diatur dalam perjanjian kerja, peraturan perusahanan, atau perjanjian kerja bersama.

Pasal 156 mengatur masa kerja dan besaran pesangon yang wajib diberikan oleh perusahaan kepada pekerja. Pasal ini juga mengatur uang penghargaan dan uang pengganti hak yang seharusnya diterima. Isi dari pasal ini adalah jika terjadi pemutusan hubungan kerja (PHK), pengusaha wajib membayar uang pesangon dan/atau penghargaan masa kerja dan uang penggantian hak yang harus diterima dengan ketentuan: (a) masa kerja kurang dari 1 tahun sebanyak 1 satu bulan upah; (b) masa kerja 1 tahun atau lebih tetapi kurang dari 2 tahun, sebanyak 2 dua bulan upah; (c) masa kerja 2 tahun atau lebih tetapi kurang dari 3 tiga tahun, sebanyak 3 tiga bulan upah; (d) masa kerja 3 tahun atau lebih tetapi kurang dari 4 tahun, sebanyak 4 bulan upah; (e) masa kerja 4 tahun atau lebih tetapi kurang dari 5 tahun, sebanyak 5 (lima) bulan upah; (f) masa kerja 5 tahun atau lebih tetapi kurang dari 6 tahun, sebanyak 6 bulan upah; (g) masa kerja 6 tahun atau lebih tetapi kurang dari 7 tahun, sebanyak 7 bulan upah; (h) masa kerja 7 tahun atau lebih tetapi kurang dari 8 tahun, sebanyak 8 bulan upah; dan (i) masa kerja 8 tahun atau lebih, sebanyak 9 bulan upah.

Uang penghargaan masa kerja diberikan paling banyak sesuai ketentuan: (a) masa kerja 3 tahun atau lebih tetapi kurang dari 6 tahun, sebanyak 2 bulan upah; (b) masa kerja 6 tahun atau lebih tetapi kurang dari 9 tahun, sebanyak 3 bulan upah; (c) masa kerja 9 tahun 
atau lebih tetapi kurang dari 12 tahun, sebanyak 4 bulan upah; (d) masa kerja 12 tahun atau lebih tetapi kurang dari 15 tahun, sebanyak 5 bulan upah; (e) masa kerja 15 tahun atau lebih tetapi kurang dari 18 tahun, sebanyak 6 bulan upah; (f) masa kerja 18 tahun atau lebih tetapi kurang dari 21 tahun, sebanyak 7 bulan upah; (g) masa kerja 21 tahun atau lebih tetapi kurang dari 24 tahun, sebanyak 8 bulan upah; dan (h) masa kerja 24 tahun atau lebih, sebanyak 10 bulan upah. Uang penggantian hak yang seharusnya diterima meliputi: (a) cuti tahunan yang belum diambil dan belum gugur; (b) biaya atau ongkos pulang untuk pekerja/buruh dan keluarganya ke tempat di mana pekerja/buruh diterima bekerja; dan (c) hal-hal lain yang ditetapkan dalam perjanjian kerja, peraturan perusahaan atau perjanjian kerja bersama.

Pasal 157 berisi mengenai ketentuan pemberian uang pesangon, uang penghargaan masa kerja, dan uang penggantian hak. Pasal ini menyatakan bahwa komponen upah yang digunakan sebagai dasar perhitungan uang pesangon dan uang penghargaan masa kerja, terdiri atas upah pokok dan tunjangan tetap yang diberikan kepada pekerja/buruh dan keluarganya. Pekerja/buruh yang upahnya dibayarkan atas dasar perhitungan harian, upah sebulan sama dengan 30 dikali upah sehari. Jika pekerja/buruh yang upahnya dibayarkan atas dasar perhitungan satuan hasil, upah sebulan sama dengan penghasilan rata-rata dalam 12 bulan terakhir. Jika upah sebulan lebih rendah dari upah minimum, maka upah yang menjadi dasar perhitungan pesangon adalah upah minimum yang berlaku di wilayah domisili perusahaan. Hal yang sama dengan jam kerja yang disangkakan oleh masyarakat. Sejatinya, substansi undang-undang itu mengatur tentang waktu bukan merujuk kepada jam. Pekerja dibayar berdasarkan satuan hasil dan atau satuan waktu. Undang-undang terdahulu yang sudah berjalan juga demikian. Pembayaran berdasarkan satuan hasil atau satuan waktu.

Perbandingan asumsi publik dengan isi pasal undang-undang dapat dilihat pada tabel 1.

Tabel 1. Perbandingan Aasumsi Publik dengan Isi pasal 79, 156, 88B, dan 178

\begin{tabular}{|c|c|c|}
\hline No & Asumsi Publik & Penjelasan \\
\hline \multirow[t]{2}{*}{1} & Cuti dihilangkan & Pasal 79 \\
\hline & & $\begin{array}{l}\text { Menjelaskan pengusaha wajib memberi waktu } \\
\text { istirahat dan cuti }\end{array}$ \\
\hline \multirow[t]{2}{*}{2} & Pesangon dihilangkan & Pasal 156 \\
\hline & & $\begin{array}{l}\text { Menjelaskan dalam hal terjadinya pemutusan hubungan } \\
\text { kerja, pengusaha wajib membayar uang pesangon } \\
\text { dan/atau uang penghargaan masa kerja dan uang } \\
\text { penggantian hak yang seharusnya diterima }\end{array}$ \\
\hline \multirow[t]{2}{*}{3} & Pekerja dibayar & Pasal 88B \\
\hline & hitungan jam & $\begin{array}{l}\text { Menjelaskan upah ditetapkan berdasarkan satuan waktu } \\
\text { dan atau satuan hasil }\end{array}$ \\
\hline \multirow[t]{2}{*}{4} & Merusak lingkungan & Pasal 178 \\
\hline & & $\begin{array}{l}\text { Menjelaskan setiap pemilik perizinan berusaha yang } \\
\text { melaksanakan kegiatan/usahanya menimbulkan } \\
\text { dampak kerusakan pada lingkungan hidup, selain } \\
\text { dikenai sanksi administratif sebagaimana dimaksud } \\
\text { dalam Pasal } 156 \text { ayat (5), pemilik perizinan berusaha } \\
\text { wajib memulihkan kerusakan lingkungan akibat dari } \\
\text { kegiatan/usahanya }\end{array}$ \\
\hline
\end{tabular}

Sumber : data primer dan sekunder yang diolah

Dapat dikatakan opini publik negatif yang tercipta berdasarkan penjelasan di atas, karena kurangnya informasi yang didapatkan oleh masyarakat terkait substansi undangundang tersebut. Lebih jauh responden ditanya apakah melihat upaya pemerintah menjelaskan substansi undang-undang $63,6 \%$ di antaranya menjawab tidak melihat adanya upaya pemerintah, dan hanya $36,4 \%$ yang mengatakan telah ada upaya dari pemerintah. Bahkan, ketika ditanya apakah upaya pemerintah sudah maksimal dalam menjelaskan 
substansi undang-undang, 100\% responden sepakat tidak maksimal. Hampir seluruh responden juga menilai kekurangan pemerintah adalah kurangnya sosialisasi terkait substansi undang-undang tersebut. Pemerintah dinilai kurang transparan yang mana seharusnya dibuka seluas-luasnya sehingga masyarakat mengetahui yang sebenarnya dan tidak terbentuk negatif opini publik. Opini publik tentang undang-undang tersebut bisa dihindari jika saja pemerintah membangun komunikasi melalui melalui media, baik media massa maupun media sosial yang berisi tentang kelebihan dan keuntungan diberlakukannya undang-undang tersebut. Pemerintah seharusnya juga lebih menguatkan lagi sosialisasi yang melibatkan kelompok masyarakat maupun mahasiswa tentang isi undang-undang tersebut.

Pandangan tersebut didasarkan pada jumlah responden yang lebih mempercayai media daripada saluran lainnya. Efek dan citra yang baik-bisa saja dilakukan pemerintah dengan memanfaatkan media. Melalui media massa atau media sosial, pemerintah bisa membuat suatu program yang khusus membahas substansi isi undang-undang, sehingga masyarakat bisa mengetahui lebih jauh keuntungan diberlakukannya regulasi baru. Pemerintah seharusnya menyediakan anggaran untuk membuat program tersebut. Bahkan, jika diperlukan program tersebut dilaksanakan secara terus menerus. Informasi tentang undang-undang tersebut harus dipaparkan setiap hari sehingga opini masyarakat berubah dari negatif menjadi positif.

\section{SIMPULAN DAN REKOMENDASI}

\section{Simpulan}

Penyebab terciptanya opini publik negatif tentang UU Ciptaker sehingga berujung demonstrasi di Kalsel karena kurangnya informasi dan pengetahuan para demonstran terhadap substansi undang-undang tersebut. Hal ini diketahui dari jawaban responden yang justru bertentangan dengan isi undang-undang. Publik mempunyai asumsi yang menyatakan bahwa hadirnya undang-undang tersebut lebih banyak menguntungkan pengusaha dan merugikan masyarakat. Padahal jika ditelaah lebih jauh undang-undang sudah mengatur kebutuhan publik, contohnya pasal kewajiban pesangon yang dianggap publik dihilangkan. Berdasarkan keterangan responden yang menjawab 100\% sosialisasi pemerintah kurang maksimal, dapat disimpulkan bahwa upaya yang ditempuh pemerintah selama ini perlu lebih masif lagi. Di tengah hadirnya media sosial, urusan pemerintahan publik masih lebih percaya dengan media massa. Hal ini dapat diketahui dari lebih banyak responden yang mengetahui hadirnya undang-undang cipta kerja melalui media massa.

\section{Rekomendasi}

Pemerintah perlu melakukan sosialisasi tentang substansi isi undang-undang tersebut. Dalam melaksanakan sosialisasi, agar lebih menyentuh masyarakat, pemerintah perlu melibatkan publik figur, tokoh agama, tokoh masyarakat, kelompok mahasiswa, kelompok masyarakat, bahkan selebgram atau youtubers. Sosialisasi tersebut agar masyarakat bisa mempelajari substansi isi undang-undang tersebut sebelum membuat suatu kesimpulan atau penilaian. Pemerintah juga perlu memanfaatkan media massa sebagai sarana sosialisasi bahkan harus dilakukan secara terus menerus. Dalam hal sosialisasi pemerintah harus membuat suatu program khusus yang disajikan melalui media massa dan media sosial. Pemerintah harus membuat freaming yang disajikan melalui media massa dan media sosial tentang pasal-pasal kelebihan atau keuntungan diberlakukannya undangundang tersebut. 


\section{DAFTAR PUSTAKA}

Cangara, H. 2011. Komunikasi Politik : Konsep, Teori dan Strategi. jakarta : Raja Grafindo Persada.

Heryanto, Gun Gun. 2020. Realitas Komunikasi Politik Indonesia Kontemporer . Yogyakarta: IRCiSoD.

Indonesia, Pemerintah Republik. 2020. Undang-undang No. 11 Tahun 2020 tentang Cipta Kerja. Berita Negara Republik Indonesia Tahun 2020, Jakarta: Pemerintah Republik Indonesia.

Indrawan, R. M. Jerry. 2017. "Dampak Komunikasi Politik dan Opini Publik Terhadap Perilakau Masyarakat." Wacana Volume 16 No 2 171-179.

Melisaa. 2013. "Pembentukan Opini Publik Tentang Citra Polisi Terkait Berita TIndak Kekerasan Polisi di Harian Samarinda Pos Studi Deskriptif Pada Masyarakat Kelurahan Bandara Samarinda." eJournal Ilmu Komunikasi Volume 1 Nomor 2 236-248.

Rianto, Puji. 2010. "Opini Publik, Agenda Setting, dan Kebijakan Publik.” Komunikasi Volume 5 No 1 31-40.

Sirait, Partahi Fernando Wilbert dan Cindoswari, Ageng Rara. 2018. "Pengaruh Program Televisi Detak Kepri, dan Opini Publik." Jurnal Komunikasi dan Media Volume 3 No.1 93-101.

Sofian, M. Ali, Laksono, Puji, dan Chabibi Muhammad. 2020. "Strategi Komunikasi Politik Ulama Nahdlatul Wathan Pancor Dalam Membentuk Opini Publik Pilkada Pada Pemilihan Umum Presiden Tahun 2019." Jurnal Al-Tsiqoh (Dakwah dan ekonomi) Volume 5 No. 2 57-73.

Tabroni, Roni. 2012. Komunikasi Politik Pada Era Multimedia. Bandung: Simbiosa Rekatama Media.

Trijanto, Danang. 2015. "Relasi Antara Opini Publik dan Media Massa (Pembentukan Opini Publik Melalui Iklan Politik di MNC dan Metro TV)." Promedia Volume 1 No 2 21-37.

Wanodya, Ayusta Gilang. 2018. "Penyetiran Opini Publik di Media Massa : Telaah Teori Konspirasi atas Pelemahan Islam." Fikrah : Jurnal Ilmu Aqidah dan Studi Keagamaan Volume 6 No. 1 117-140. 